\title{
Mikroklimat, Termoregulasi dan Produktivitas Sapi Perah Friesians Holstein pada Ketinggian Tempat Berbeda
}

\author{
Elmy Mariana ${ }^{1 *}$, Cece Sumantri², Dewi Apri Astuti ${ }^{3}$, Anneke Anggraeni $^{4}$, \\ Asep Gunawan ${ }^{3}$ \\ ${ }^{1}$ Fakultas Pertanian Universitas Syiah Kuala, \\ Kampus Kopelma Darussalam Banda Aceh, 23111 \\ dan Sekolah Pascasarjana Institut Pertanian Bogor, Kampus IPB Dramaga, Bogor, 16680 \\ ${ }^{2}$ Department Ilmu Produksi dan Teknologi Peternakan, Institut Pertanian Bogor \\ ${ }^{3}$ Department Ilmu Nutrisi dan Teknologi Pakan, Institut Pertanian Bogor \\ Kampus IPB Dramaga, Bogor, 16680 \\ ${ }^{4}$ Balai Penelitian Ternak, Jl. Veteran III, PO. BOX 221 Ciawi Bogor 16002 \\ *Email korespondensi: elmy_mariana@unsyiah.ac.id
}

(Diterima: 14 Desember 2018; disetujui: 5-1-2019)

\begin{abstract}
ABSTRAK
Tujuan penelitian ini adalah untuk mengetahui pengaruh ketinggian tempat terhadap kondisi mikroklimat,termoregulasi dan produktivitas sapi Friesian-Holstein (FH). Penelitian dilakukan pada tiga lokasi dengan ketinggian berbeda, yaituPodok Ranggon (97mdpl), Ciawi (576mdpl), dan Lembang (1241mdpl). Sebanyak 63 sapi FH dalam kondisi laktasi normal digunakan dalam penelitian ini. Aspek lingkungan meliputi suhu udara, kelembaban relatif dan Temperature-Humidity Index di dicatat setiap 2 jam dari pukul 08.00 sampai 16.00 WIB. Parameter termoregulasi yang diamati terdiri atas suhu kulit (Ts),suhu rektal ( $\mathrm{Tr}$ ), suhu tubuh (Tb), denyut jantung (Hr),laju pernapasan ( $\mathrm{Rr}$ ), dan Heat Tolerance Coeficient (HTC).Berdasarkan nilai $\mathrm{Ta}, \mathrm{Rr}$ dan THI, dataran rendah memberikan dampak cekaman panas sedang, dataran sedangdan tinggi memberikan dampak cekaman panas ringan pada sapi perah. Hasil menunjukkan bahwa sapi dataran rendah memiliki Nilai HTC, Tr, Ts dan Tb tertinggi $(\mathrm{P}<0,05)$ dan $\mathrm{Hr}$ yang terendah $(\mathrm{P}<0,05)$. Produksi susu di ketiga lokasi penelitian berbeda nyata $(\mathrm{P}<0,05)$, dengan produksi susu tertinggi di dataran tinggi $(13,1 \pm 3,52 \mathrm{~kg})$, dataran sedang $(11,3 \pm 4,73 \mathrm{~kg})$ dan dataran rendah $(7,0 \pm 3,36 \mathrm{~kg})$. Secara umum sapi $\mathrm{FH}$ di dataran rendah, sedang dan tinggi tercekam panas akibat kondisi lingkungan yang berada pada kondisi di luar zona nyamanselama musim kemarau, akan tetapi mampu beradaptasi terhadap kondisi tersebut.
\end{abstract}

Kata kunci: ketinggian tempat, produktivitas, sapi perah, cekaman panas, termoregulasi

\section{ABSTRACT}

The purpose of this research was to determine altitude effect on microclimate, thermoregulation and productivity of Friesian Holstein. Research was conducted in different altitudes, i.e.: Pondok Ranggon (97m asl), Ciawi (576m asl), and Lembang (1241 m asl). A total of $63 \mathrm{FH}$ cows in normal lactation were used in this study. Microclimate aspects observation includes environmental temperature (Ta), relative humidity (RH) and Temperature-Humidity Index (THI) were recorded every 2 hours from 08.00 to 16.00 . The physiological responses measurements consisted of skin temperature (Ts), rectal temperature $(\mathrm{Tr})$, body temperature $(\mathrm{Tb})$, heart rate $(\mathrm{Hr})$, respiratory rate $(\mathrm{Rr})$ and Heat Tolerance Coeficient (HTC). Lowland environmental provide moderate heat stress, while the medium and highland impacts with mild stress. The results showed that lowland cows have highest HTC, Tr, Ts and $\mathrm{Tb}(\mathrm{P}<0.05)$ and lowest $\operatorname{Hr}(\mathrm{P}<0.05)$. Milk production in the different altitude was significantly different $(\mathrm{P}<0.05)$, with the highest milk yields in the highlands $(13.1 \pm 3.52 \mathrm{~kg})$, medium $(11.3 \pm 4.73 \mathrm{~kg})$ and lowland $(7.0 \pm 3.36 \mathrm{~kg})$. In general, HF dairy cows in low-, medium- and highland are exposed to climatic stress during dry season conditions, although they have the ability to adapt physiologically and cope with environmental stress.

Keyworlds: altitude, dairy cattle, heat stress, productivity, physiological responses 


\section{PENDAHULUAN}

Permintaan susu nasional yang terus meningkat setiap tahun harus diimbangi dengan peningkatan produksi susu nasional. Sebagian besar susu yang diproduksi di dalam negeri adalah dari usaha sapi perah, dengan demikian dalam acuan peningkatan produksi susu nasional, populasi maupun skala usaha sapi perah harus lebih ditingkatkan. Selama ini usaha sapi perah masih terkonsentrasi pada daerah-daerah berdataran tinggi, seperti Pangalengan, Lembang, Baturaden, Batu, Pujon dan Nongkojajar. Namun demikian tidak berarti usaha sapi perah tidak mempunyai peluang untuk berkembang di daerah-daerah dataran rendah.

Dataran rendah adalah wilayah yang ditandai dengan suhu lingkungan dan kelembaba nudara yang tinggi, hal ini merupakan faktor pembatas yang menonjol dalam pengembangan usaha sapi perah. Peluang pengembangan usaha sapi perah di dataran rendah dapat dilakukan apabila berbagai kendala yang menghambatnya dapat ditanggulangi. Suhu udara dan kelembaban merupakan faktor terpenting yang membentuk iklim dan sangat mempengaruhi proses adaptasi dan distribusi ternak dan vegetasi. Suhu udara yang relatif panas dengan kelembaban udara yang tinggiberdampak negatif terhadap kemampuan produksi dan reproduksi sapi perah (Purwanto et al., 1993; Atrian dan Shahryar 2012). Sapi perah berproduksi dengan baik pada kondisi lingkungan yang nyaman (comfort zone), dengan batas maximum dan minimum temperatur dan kelembaban lingkungan berada pada zona nyaman. Di luar kondisi ini sapi perah akan mengalami cekaman sehingga mengalami penurunan produksi (Purwanto et al., 1993; Nardone et al., 2010), dan kualitas susu (Hill \& Wall, 2015). Cekaman panas yang dialami ternak berpengaruh pada penurunan produksi susu sebesar $0.6-1.4 \mathrm{~kg}$ setiap peningkatan temperatur udara sebesar $1{ }^{\circ} \mathrm{C}$, (Atrian dan Shahryar 2012). St-Pierre et al. (2003) menyatakan bahwa industri sapi perah di Amerika serikat mengalami kerugian ekonomi sebesar USD 900 juta per tahun akibat penurunan produksi susu karena cekaman panas.

Di bawah cekaman panas, sapi perah beradaptasi dengan meningkatkan pembuangan panas melalui penguapan kulit dan pernapasan, dan hal ini berakibat pada penurunan konsumsi pakan, redistribusi aliran darah, penurunan kekebalan tubuh, perubahan laju metabolisme dan perubahan fungsi endokrin (Marai et al.,
2007). Perubahan fisiologi merupakan dasar dari termoregulasi untuk menjaga kestabilan susu badan dan mencegah hipertermia. Penelitian yang mempelajari pengaruh kondisi lingkungan dengan ketinggian yang berbeda sangat jarang dilakukan di Indonesia. Oleh karena itu, penelitian ini bertujuan untuk mengetahui pengaruh ketinggian yang berbeda terhadap kondisi mikroklimat, kemampuan termoregulasi dan produktivitas sapi perah FH di Indonesia. Hasil penilaian tersebut dapat menjadi dasar pedoman dalam perumusan strategi pengembangan sapi perah pada kondisi ketinggian lingkungan yang berbeda secara tepat dan berkelanjutan.

\section{MATERI DAN METODE}

\section{Waktu dan Tempat Penelitian}

Penelitian dilakukan pada peternakan sapi perah dataran rendah yang berlokasi di Pondok Ranggon (97 mdpl), dataran sedang yang berlokasi di Ciawi (574 mdpl) dan dataran tinggi yang berlokasi di Lembang (1241 mdpl). Penelitian dilaksanakan pada bulan Mei sampai Oktober 2015. Pemilihan waktu pengambilan sampel didasarkan pada kondisi musim kemarau dengan curah hujan terendah dan temperatur lingkungan tertinggi berdasarkan data BMKG.

\section{Materi Penelitian}

Sapi perah yang digunakan dalam penelitian ini adalah FH laktasi dengan kisaran bulan laktasi 2-4 bulan dan periode laktasi 2-4. Sapi yang digunakan sebanyak 63 ekor dengan rincian Pondok Ranggon 29 ekor, Ciawi 15 ekor dan Cikole 19 ekor. Pemilihan sampel dengan metode purposive sampling. Ternak ditempatkan pada kandang dengan fasilitas tempat pakan dan air yang memadai dan dipelihara dengan baik berdasarkan standar good dairy farming fractises (FAO, 2011). Pakan yang diberikan berupa hijauan, konsentrat dan pakan tambahan yang memenuhi kebutuhan ternak berdasarkan NRC (2001). Pemerahan dilakukan di kandang dengan menggunakan mesin perah.

\section{Parameter Pengamatan}

Parameter yang akan diamati pada penelitian ini adalah kondisi mikroklimat, respons fisiologi, ambang cekaman panas dan produksi susu. Data kondisi mikroklimat diukur setiap 2 jam sekali mulai pukul 08.00 sampai 16.00 WIB. Suhu dan kelembaban udara diukur dengan alat termometer bola basah dan bola kering (dry-wet, Sanghai). Indeks suhu 
kelembaban (THI) dihitung menggunakan rumus Hahn (1999), yaitu:

$$
\mathrm{THI}=\mathrm{DBT}+0.36 \mathrm{WBT}+41.2
$$

dengan DBT adalah suhu bola kering $\left({ }^{\circ} \mathrm{C}\right)$ dan WBT adalah suhu bola basah $\left({ }^{\circ} \mathrm{C}\right)$.

Parameter respons fisiologi yang diamati meliputi suhu permukaan kulit (Ts), suhu rektal ( Tr), suhu tubuh $(\mathrm{Tb})$, denyut jantung $(\mathrm{Hr})$ dan frekuensi respirasi (Rr).Tr diukur dengan memasukkan termometer rektal (SAFETY, Japan) ke dalam rektal sedalam $\pm 10 \mathrm{~cm}$ selama tiga menit. Ts diukur dengan termometer inframerah (Traceable MiniIR ${ }^{\mathrm{TM}}$ Thermometer, Friendswood, Texas, USA)pada empat titik yaitu punggung (A), dada (B), tungkai atas (C), dan tungkai bawah (D). Rataan suhu permukaaan kulit dihitung berdasarkan modifikasi rumus McLean et al. (1983).

$$
\begin{gathered}
\mathrm{Ts}=0.25(\mathrm{~A}+\mathrm{B})+0.32 \mathrm{C}+0.18 \mathrm{D} \\
\mathrm{Tb}=0.86 \mathrm{Tr}+0.14 \mathrm{Ts} .
\end{gathered}
$$

$\mathrm{Hr}$ diukur dengan menempelkan stetoskop (STETOSCOPE, Japan) di dekat tulang axilla sebelah kiri selama satu menit. Rr diukur dengan cara menempelkan stetoskop di dada untuk menghitung inspirasi dan ekspirasi pernafasan selama satu menit. Pengukuran $\mathrm{Ts}, \mathrm{Tr}, \mathrm{Tb}, \mathrm{Rr}$, dan $\mathrm{Hr}$ setiap hari pada pukul 08.00, 12.00, dan 16.00 WIB.
Penghitungan ambang cekaman panas (Heat Tolerance Coefisien/HTC) di dasarkan pada kecepatan respirasi tiap menit dan temperatur rektal. HTC dihitung dengan koefisien Benezra (1954) sebagai berikut:

$$
H T C=\frac{T b}{38.3}+\frac{R r}{23}
$$

dengan $\mathrm{Tb}$ adalah rataan harian suhu tubuh $\left({ }^{\circ} \mathrm{C}\right)$, $\mathrm{Rr}$ adalah rataan frekuensi pernafasan selama 1 menit, 38.3 adalah angka standar suhu normal sapi perah dan 23 adalah angka standar frekuensi pernafasan selama 1 menit.

Pengukuran produksi susu dilakukan pada pemerahan pagi dan sore hari. Data produksi susu merupakan data rerata produksi susu selama 305 hari dan produksi susu yang dikoreksi dengan 4\% FCM (fat corrected milk).

Produksi susu $4 \% \mathrm{FCM}=(0.4 \times \mathrm{PS})+(15 \times \mathrm{PS} \times$ L)

dengan PS adalah produksi susu rata-rata harian dan $\mathrm{L}$ adalah persentase kadar lemak.

\section{Analisis Data}

Data mikroklimat, respons fisiologi, ambang cekaman panas, dan produksi susu dianalisis dengan pendekatan General Linear Model. Pengujian dilakukan berdasarkan perbedaan lokasi penelitian dan jika respons menunjukkan perbedaan $(\alpha=0,05)$ dilakukan pengujian lanjut dengan metode uji beda Duncan.

Tabel 1 Rataan kondisi mikroklimat di lokasi penelitian

\begin{tabular}{lccc}
\hline Parameter & \multicolumn{3}{c}{ Ketinggian } \\
\cline { 2 - 4 } & Dataran rendah & Dataran sedang & Dataran tinggi \\
\hline Ta (oC) & $33,1 \pm 3,91^{\mathrm{a}}$ & $28,9 \pm 9,01^{\mathrm{b}}$ & $25,7 \pm 4,41^{\mathrm{c}}$ \\
RH (\%) & $61,8 \pm 15,40^{\mathrm{a}}$ & $57,2 \pm 14,02^{\mathrm{ab}}$ & $56,7 \pm 14,82^{\mathrm{b}}$ \\
THI & $83,5 \pm 4,19^{\mathrm{a}}$ & $78,3 \pm 9,33^{\mathrm{b}}$ & $73,8 \pm 5,10^{\mathrm{c}}$ \\
\hline
\end{tabular}

Ta: suhu lingkungan, RH: kelembapan relatif, THI: Temperature Humidity Index

Superskrip yang berbeda pada baris yang sama menunjukkan perbedaan nyata $(\mathrm{P}<0.05)$.

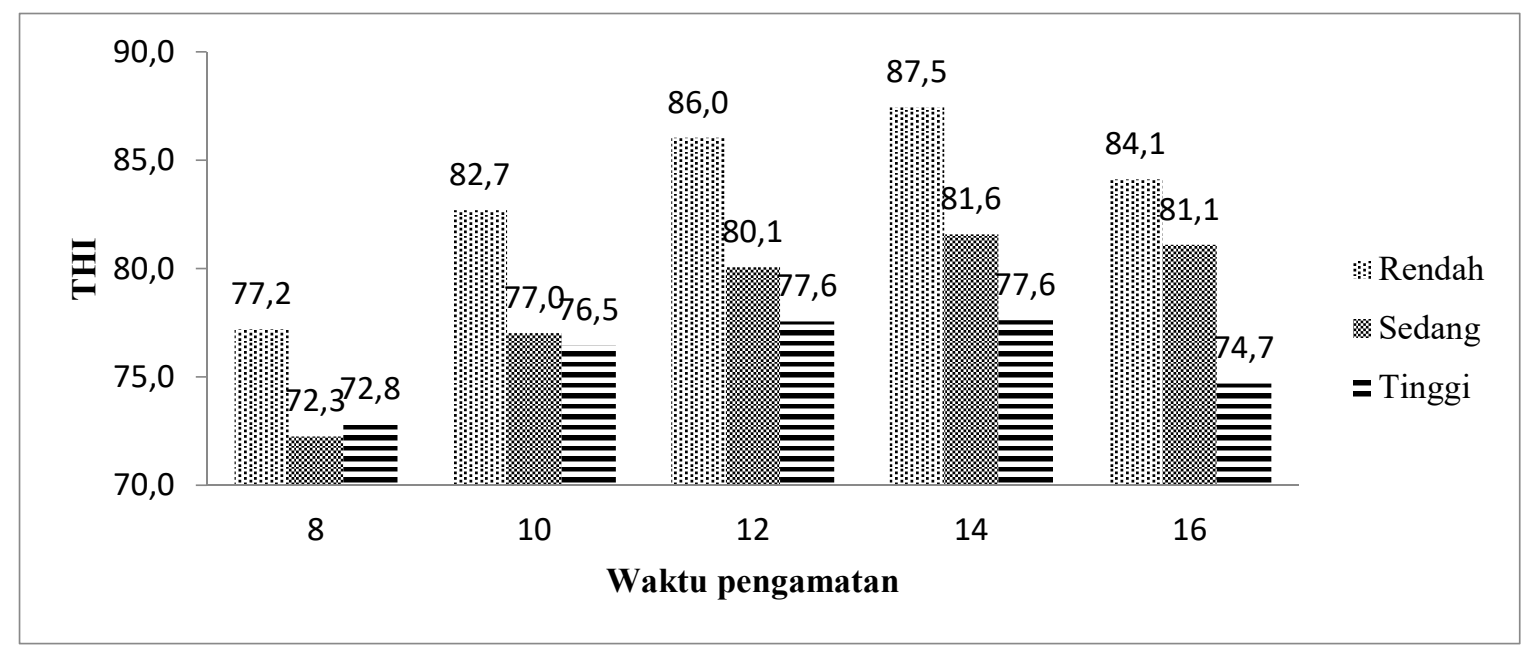

Gambar 1. Temperature humidity index (THI) pada dataran rendah, sedang dan tinggi 


\section{HASIL DAN PEMBAHASAN}

\section{Kondisi Lingkungan}

Penelitian dilakukan pada tiga lokasi peternakan sapi perah dengan ketinggian berbeda. Kondisi mikroklimat pada ketiga lokasi penelitian disajikan pada Tabel 1. Hasil analisis ragam menunjukan perbedaan ketinggian tempat berpengaruh $\quad(\mathrm{P}<0.05) \quad$ terhadap kondisi mikroklimat yaitu suhu udara, kelembaban relative dan nilai THI. Nilai THI, suhu udara dan kelembaban relatif dalam kandang yang terendah adalah di dataran tinggi, diikuti oleh dataran sedang dan dataran rendah. Variasi suhu udara selama pengamatan berkisar dari $23,6-36,7^{\circ} \mathrm{C}$, kelembaban udara 43,4-81,6\% dengan THI 7,.387,5 . Nilai rerata temperatur udara pada ketiga lokasi lebih tinggi jika dibandingkan rerata suhu udara di ketiga lokasi penelitian selama 10 tahun. Hal ini disebabkan pada tahun 2015 Indonesia mengalami kondisi El-nino di mana musim kemarau menjadi lebih panjang disertai peningkatan suhu udara (BMKG, 2015). Nilai pengamatan THI yang diperoleh lebih tinggi dari nilai optimum untuk kenyamanan sapi perah yaitu THI kurang dari 72. Menurut Atrian dan Shahryar (2012) tingkatcekaman panas berdasarkan nilai THI dikategorikan menjadi 4 kelompok yaitu:cekaman ringan (THI 72-78), cekaman sedang (THI 79-88), cekaman berat (THI 89-98) dan cekaman sangat berat (THI $>98$ ). Berdasarkan nilai THI, lingkungan dataran rendah memberikan dampak cekaman sedang, sementara dataran sedang dan tinggi memberikan dampak cekaman ringan pada sapi perah. Puncak THI dicapai pada pukul 14.00 siang untuk dataran rendah dan sedang, sedangkan pada dataran tinggi terjadi pada pukul 12.00 seiring dengan meningkatnya temperatur udara. Kondisi tersebut serupa dengan penelitian Yani dan Purwanto (1996) yang melaporkan bahwa suhu lingkunganmencapai pada puncak pukul 12.0014.00 WIB dan turun menjelang sore hari, sedangkankelembaban udara menunjukkan pola yang sebaliknya.

Kondisi lingkungan mikro di lokasi penelitian, menggambarkan bahwa suhu udara berbanding terbalik dengan nilai kelembapan relatif di suatu lingkungan. Pada pagi hari suhu kandang berkisar $25,1^{\circ} \mathrm{C}$ pada pukul $08.00 \mathrm{WIB}$, meningkat di siang hari yang mencapai puncak panas, yaitu $32,6^{\circ} \mathrm{C}$ pada pukul 14.00 WIB dan turun pada suhu $30,4^{\circ} \mathrm{C}$ pada pukul 16.00 WIB. Berbeda darikelembapanrelatif pada pagi hari pukul 08.00 WIB berkisar 73,1\%, siang hari pukul 14.00 WIB mencapai titik terendah, yaitu $47,0 \%$ dan sore hari pukul 16.00 WIB kembali meningkat yaitu $56,2 \%$. Hubungan suhu lingkungan dankelembapanrelatifdi lokasi penelitian digambarkan pada Gambar 2.Hubungan suhu lingkungan dengan kelembapanrelatif menciptakan suatu kondisi cekaman atau tidaknya ternak. Nilai THI dengan suhu lingkungan mengilustrasikan pola perubahan yang baku, yaitu pola parabolik (Gambar 2).

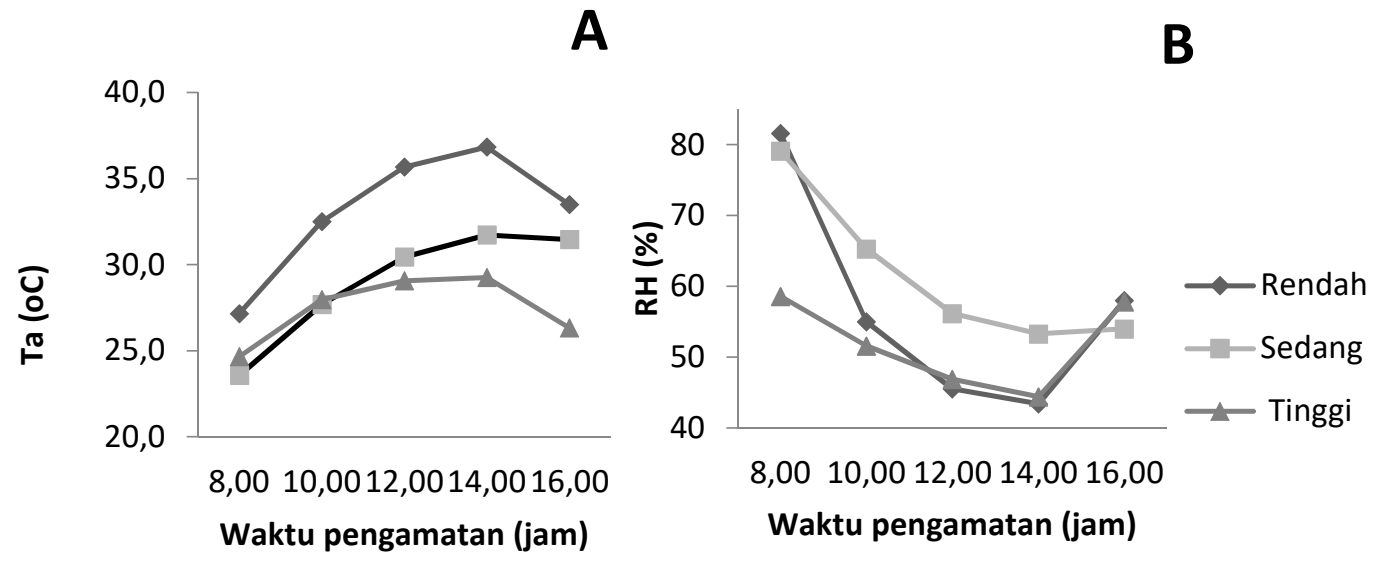

Gambar 2. Polaperubahan suhu udara (A) dan kelembapanrelatif (B) pada dataran rendah, sedang dan tinggi.

\section{Respons Fisiologi dan Kemampuan Termoregulasi}

Kondisi cekaman pada sapi perah FH dapat ditentukan melalui nilai THI dan respons fisiologi sapi perah. Hasil pengukuran responsfisiologi di tiga lokasi penelitian disajikan pada Tabel 2. Hasil analisis ragam menunjukan bahwa ketinggian tempat dan waktu pengamatan berpengaruh terhadap respons fisiologi sapi perah 
yang berupa $\mathrm{Rr}, \mathrm{Hr}, \mathrm{Tr}$, $\mathrm{Ts}$, $\mathrm{Tb}$, dan $\mathrm{HTC}$ $(\mathrm{P}<0,05)$. Nilai Tr, Ts, dan Tbpada dataran rendah lebih tinggi dibandingkan dengan dataran sedang dan tinggi. Nilai tertinggi $\mathrm{Tr}, \mathrm{Ts}$, Tbdari ketiga lokasi adalah $38,6 \pm 0,56 ; 34,1 \pm 0,70$ dan $37,9 \pm 0,56$. Hasil tersebut termasuk dalam kriteria suhu tubuh normal untuk sapi perah laktasi menurut Schütz et al.(2011).

Sapi pada dataran sedang memiliki $\mathrm{Tr}$ dan $\mathrm{Tb}$ yang sama dengan dataran tinggi, tetapi memiliki Ts yang lebih tinggi. Hal ini disebabkan karena kecepatan angin di dataran sedang lebih rendah dari dataran tinggi sehingga pelepasan panas ke lingkungan melalui radiasi kulit berjalan lebih lambat jika dibandingkan dengan di dataran tinggi. Pengukuran suhu rektal tertinggi dicapai pada pukul 4sore pada ketiga lokasi penelitian. Hal ini dimungkinkan karena pengaruh suhu lingkungan yang mencapai puncaknya pada pukul 14.00 dan adanya tambahan panas dari proses pencernaan pakan. Pada ketiga lokasi penelitian, sapi diberikan pakan pada pukul 15.00 wib atau setelah pemerahan. Menurut Purwanto et al. (1990) puncak produksi panas tubuh meningkat setelah 3 jam ternak makan.

Nilai rataan Tr di ketiga lokasi penelitian lebih rendah dari kisaran normal yakni 38,00$39,30^{\circ} \mathrm{C}$,(Mirzadeh, 2010). Nilai rataan tersebut menunjukkan bahwa kondisi lingkungan masih memungkinkan bagi sapi

Tabel 2 Respons fisiologi sapi perah FH pada ketinggian tempat dan waktu pengukuran yang berbeda

\begin{tabular}{|c|c|c|c|c|c|}
\hline \multirow{2}{*}{ Parameter } & \multirow[t]{2}{*}{ Jam } & \multicolumn{4}{|c|}{ Ketinggian tempat } \\
\hline & & Dataran Rendah & Dataran sedang & Dataran Tinggi & Rataan \\
\hline \multirow[t]{4}{*}{$\operatorname{Tr}\left({ }^{\circ} \mathrm{C}\right)$} & 08,00 & $37,5 \pm 1,26$ & $37,4 \pm 0,65$ & $37,4 \pm 3,09$ & $37,5 \pm 0,07^{\mathrm{B}}$ \\
\hline & 12,00 & $38,3 \pm 0,43$ & $38,0 \pm 0,64$ & $38,0 \pm 0,53$ & $38,1 \pm 0,07^{\mathrm{A}}$ \\
\hline & 16,00 & $38,6 \pm 0,56$ & $38,3 \pm 0,46$ & $38,1 \pm 0,99$ & $38,3 \pm 0,07^{\mathrm{A}}$ \\
\hline & Rataan & $38,1 \pm 0,08^{\mathrm{a}}$ & $37,9 \pm 0,07^{\mathrm{b}}$ & $37,8 \pm 0,07^{\mathrm{b}}$ & \\
\hline \multirow[t]{4}{*}{$\operatorname{Ts}\left({ }^{\circ} \mathrm{C}\right)$} & 08,00 & $31,1 \pm 1,33$ & $29,8 \pm 1,29$ & $31,0 \pm 1,32$ & $30,5 \pm 0,06^{\mathrm{C}}$ \\
\hline & 12,00 & $34,7 \pm 1,43$ & $34,0 \pm 0,77$ & $33,3 \pm 1,04$ & $33,9 \pm 0,06^{\mathrm{A}}$ \\
\hline & 16,00 & $33,8 \pm 1,36$ & $34,1 \pm 0,70$ & $31,9 \pm 0,91$ & $33,2 \pm 0,06^{\mathrm{B}}$ \\
\hline & Rataan & $33,2 \pm 0,07^{\mathrm{a}}$ & $32,6 \pm 0,06^{\mathrm{b}}$ & $32,1 \pm 0,06^{\mathrm{c}}$ & \\
\hline \multirow[t]{4}{*}{$\mathrm{Tb}\left({ }^{\circ} \mathrm{C}\right)$} & 08,00 & $36,6 \pm 1,14$ & $36,4 \pm 0,64$ & $36,3 \pm 3,85$ & $36,4 \pm 0,10^{\mathrm{B}}$ \\
\hline & 12,00 & $37,8 \pm 0,45$ & $37,2 \pm 2,75$ & $37,4 \pm 0,48$ & $37,4 \pm 0,10^{\mathrm{A}}$ \\
\hline & 16,00 & $37,9 \pm 0,56$ & $37,7 \pm 0,43$ & $37,2 \pm 0,89$ & $37,6 \pm 0,10^{\mathrm{A}}$ \\
\hline & Rataan & $37,4 \pm 0,11^{\mathrm{a}}$ & $37,1 \pm 0,09^{b}$ & $37,0 \pm 0,09^{b}$ & \\
\hline \multirow[t]{4}{*}{$\mathrm{Rr} /$ menit } & $08,00 \pm$ & $33,1 \pm 10,44$ & $38,5 \pm 9,30$ & $34,1 \pm 8,36$ & $35,5 \pm 0,62^{\mathrm{B}}$ \\
\hline & 12,00 & $51,0 \pm 14,76$ & $53,4 \pm 14,15$ & $38,5 \pm 10,03$ & $47,1 \pm 0,62^{\mathrm{A}}$ \\
\hline & 16,00 & $48,0 \pm 11,26$ & $57,7 \pm 14,49$ & $39,9 \pm 7,85$ & $48,6 \pm 0,62^{\mathrm{A}}$ \\
\hline & Rataan & $44,0 \pm 0,71^{\mathrm{b}}$ & $49,9 \pm 0,57^{\mathrm{a}}$ & $37,5 \pm 0,57^{\mathrm{c}}$ & \\
\hline \multirow[t]{4}{*}{$\mathrm{Hr} / \mathrm{menit}$} & 08,00 & $61,8 \pm 9,72$ & $70,1 \pm 13,91$ & $73,0 \pm 8,99$ & $69,2 \pm 0,71^{\mathrm{C}}$ \\
\hline & 12,00 & $67,8 \pm 12,27$ & $72,0 \pm 17,43$ & $77,3 \pm 10,26$ & $73,0 \pm 0,71^{\mathrm{B}}$ \\
\hline & 16,00 & $67,7 \pm 11,03$ & $75,7 \pm 16,07$ & $86,0 \pm 12,85$ & $77,7 \pm 0,71^{\mathrm{A}}$ \\
\hline & Rataan & $65,8 \pm 0,82^{\mathrm{c}}$ & $72,6 \pm 0,65^{b}$ & $78,8 \pm 0,65^{\mathrm{a}}$ & \\
\hline \multirow[t]{4}{*}{ HTC } & 08,00 & $2,4 \pm 0,46$ & $2,6 \pm 0,56$ & $2,4 \pm 0,35$ & $2,4 \pm 0,34^{\mathrm{A}}$ \\
\hline & 12,00 & $3,2 \pm 0,65$ & $3,2 \pm 0,79$ & $2,7 \pm 0,44$ & $2,9 \pm 0,48^{\mathrm{B}}$ \\
\hline & 16,00 & $3,1 \pm 0,50$ & $3,5 \pm 0,63$ & $2,7 \pm 0,34$ & $3,2 \pm 0,70^{\mathrm{C}}$ \\
\hline & Rataan & $2,9 \pm 0,65^{\mathrm{b}}$ & $3,1 \pm 0,77^{\mathrm{a}}$ & $2,6 \pm 0,40^{\mathrm{c}}$ & \\
\hline
\end{tabular}

Tr: suhu rektal, Ts: suhu kulit, Tb: suhu tubuh, Rr: kecepatan respirasi, Hr: denyut jantung, HTC: Heat Tolerance Coefficient

Superskrip huruf kecil yang berbeda pada baris yang sama menunjukkan perbedaan nyata $(\mathrm{P}<0.05)$ antar lokasi. Subskrip huruf kapital yang berbeda pada kolom yang sama menunjukkan perbedaan nyata $(\mathrm{P}<0.05)$ antar waktu pengukuran.

perah untuk menjaga kondisi homeostatis. Secara umum $\operatorname{Tr}$ dipengaruhi oleh tingkah laku, konsumsi pakan dan suhu lingkungan (Das et al. 2016). Suhu rektal merupakan hasil darimekanisme homeostatis dalam tubuh. Perubahan suhu rektal merupakan indikatorrespons sapi perah terhadap kondisi lingkungan (Nardone, 2010). Keberhasilan dalam menjaga kondisi homeostatis juga tampak dari peningkatansuhu rektal yang nilainya tidak berbeda nyata pada periode puncak cekaman (pukul 12.00-14.00).

Selain suhu rektal, kecepatan respirasi juga merupakan parameter standar indikator cekaman. Pengaruh ketinggian tempat terhadap kecepatan respirasi dapat dilihat dari perbedaan frekuensi pernafasan ternak yang menunjukkan perbedaan yang nyata $(\mathrm{P}<0.05)$ antara dataran 
rendah, sedang dan tinggi. Frekuensi respirasi pada dataran sedang $(49.9 \pm 0.57)$ lebih tinggi jika dibandingkan dengan dataran rendah dan tinggi. Hal ini menjelaskan bahwa pada sapi perah di dataran sedang pengeluaran panas yang dilakukan secara sensible tidak mencukupi untuk mengeluarkan beban panas, sehingga proses evaporasi menjadi aktif dengan meningkatkan laju pernafasan. Frekuensi respirasi merupakan indikator yang sangat sensitif dalam penetuan cekaman panas yang dialami oleh ternak (Sejian et al., 2013). Frekuensi respirasi antara 80 sampai 90 kali permenit merupakan indikasi cekaman pada sapi perah (Mirzadeh, 2010). Hal ini diperkuat dengan pernyataan Collier et al. (2006) yang menyatakan bahwa secara normal ternak memiliki kecepatan respirasi sekitar 54 kali setiap menit.

Frekuensi denyut jantung menunjukkan perbedaan yang nyata antara ketiga lokasi penelitian. Rataan denyut jantung pada penelitian ini adalah 68.5-80.0 kali/menitdengan nilai tertinggi pada dataran tinggi (78.8 \pm 0.65$)$. Perbedaan frekuensi denyut jantung pada ketiga lokasi penelitian disebabkan oleh beberapa hal antara lain perbedaan mikroklimat, ukuran tubuh dan produktivitas ternak. Aktivitas denyut jantungmemiliki hubungan yang erat dengan produksi susu dan tingkat konsumsi pakan. Sapi perah pada dataran tinggi memiliki produktivitas dan feed intake tertinggi jika dibandingkan dengan kedua lokasi yang lainnya. Menurut Purwanto et al. (1993), tingginya konsumsi pakan dapat menyebabkan meningkatnya panas tubuh ternak akibat proses metabolisme. Konsumsi energi yang tinggi menyebabkan produksi panas metabolis lebih tinggi dan selanjutnya dapat memicu peningkatan respons fisiologi termasuk denyut jantung. Hal ini diperkuat dengan pendapat Reece et al. (2015) yang menyatakan bahwa ternak menjaga keseimbangan suhu tubuhnya melalui peningkatan denyut jantung. Peningkatan denyut jantung meningkatkan penyebaran dan pelepasan panas tubuh melalui sirkulasi perifer (Das et al., 2012).

Nilai HTC tertinggi adalah di dataran sedang, sedangkan yang terendah adalah dataran tinggi. Hal ini menunjukkan bahwa sapi perah di dataran tinggi berada pada kondisi paling nyaman jika dibandingkan dengan sapi pada dataran rendah dan sedang. Hal ini diperkuat dengan nilai respirasi, suhu rektal, suhu tubuh dan suhu kulit terbaik pada sapi perah yang berada di dataran tinggi.

\section{Produksi susu}

Rerata produksi susu di ketiga lokasi penelitianberbeda nyata $(\mathrm{P}<0.05)$. Rerata produksi susu dan produksi susu distandarisasi 4\% FCM disajikan pada Tabel 3.

Tabel 3 Rataan produksi susu pada ketinggian tempat yang berbeda

\begin{tabular}{lcccc}
\hline \multicolumn{1}{c}{ Parameter } & $\begin{array}{c}\text { Dataran } \\
\text { rendah }\end{array}$ & Dataran sedang & Dataran tinggi & Rataan \\
\hline Produksi susu (kg/hari) & $7 \pm 3,36^{\mathrm{c}}$ & $11,3 \pm 4,73^{\mathrm{b}}$ & $13,1 \pm 3,52^{\mathrm{a}}$ & $9,9 \pm 4,65$ \\
Produksi susu 4\% FCM(kg/hari) & $6,5 \pm 3,73^{\mathrm{b}}$ & $11,4 \pm 6,12^{\mathrm{a}}$ & $11,7 \pm 5,29^{\mathrm{a}}$ & $9,2 \pm 5,47$ \\
\hline
\end{tabular}

superskrip yang berbeda pada baris yang sama menunjukkan perbedaan nyata $(\mathrm{P}<0,05)$.

Rerata produksi susu pada dataran tinggi lebih tinggi $16 \%$ jika dibandingkan dengan produksi pada dataran sedang dan $87 \%$ lebih tinggi jika dibandingkan dengan produksi pada dataran rendah. Perbedaan produksi susudi ketiga lokasi penelitian disebabkan olehberbagai faktor antara lain perbedaan kondisi lingkungan, pakan yang dikonsumsi sapi perah dan kondisi internal ternak itu sendiri. Secara umum ternak pada dataran tinggi berada pada kondisi lingkungan yang lebih nyaman, ukuran tubuh yang lebih besar dan konsumsi pakan yang lebih baik. Hasil analisis statistik menunjukan rataan suhu, kelembaban, THI dan konsumsi pakan di ketiga lokasi penelitian menunjukan perbedaan nyata, sehingga berpengaruh pada produksisusu.
Ditinjau dari produksi susu yang distandarisasi dengan pendekatan 4\% FCM, baik dataran sedang maupun dataran tinggi memiliki produksi susu yang sama. Hal ini disebabkan meskipun produksi susu di dataran sedang lebih rendah jika dibandingkan dataran tinggi, akan tetapi kualitas susu yang dihasilkan di dataran sedang lebih baik jika dibandingkan susu yang diproduksi di dataran tinggi. Kualitas susu yang dihasilkan oleh sapi perah di dataran tinggi lebih rendah dari pada susu dari dataran sedang dan dataran rendah pada aspek kadar lemak, protein, BK maupun BKTL. Hal ini sesuai dengan pendapat Hill \& Wall (2015) dan Rahayu et al. (2015) yang menyatakan bahwa produksi susu berbanding terbalik dengan kualitas susu. Sapi dengan produksi susu yang tinggi menghasilkan 
susu dengan kualitas yang lebih rendah jika dibandingkan dengan kualitas susu yang dihasilkan oleh sapi perah dengan produktifitas yang rendah.

Hasil penelitian menunjukkan bahwa kondisi mikroklimat yang paling ideal untuk pemeliharaan sapi perah adalah pada lokasi dataran tinggi. Setiap kenaikan ketinggian, terjadi penurunan suhudan kelembaban udaraserta peningkatan produksi susu. Hal ini disebabkan karena ternak memerlukan suhu lingkungan dankelembaban udara yang optimal untuk kehidupan dan berproduksi. Berman (2005)melaporkan bahwa sapi perah menunjukkan penampilan produksi terbaik padasuhu $18^{\circ} \mathrm{C}$ dengan kelembaban $55 \%$. Suhu dan kelembaban udara yang berada di luar zona nyaman mengakibatkan terjadinya cekaman (Silanikove, 2010; Gantner, 2017). Kondisi cekaman tertinggi yang terjadi pada dataran rendah mempengaruhi produktivitas secara nyata. Sapi perah di dataran rendah memiliki produktivitas yang lebih rendah jika dibandingkan dengan sapi perah di dataran sedang meskipun dari aspek pemeliharaan dan pemberian pakan kedua lokasi tersebut tidak berbeda. Hal ini menunjukkan bahwa pengaruh cekaman yang disebabkan oleh kondisi lingkungan sangat berpengaruh pada produktivitas ternak. Produksi susu yang rendah pada ternak di dataran rendah menggambarkan usaha adaptasi ternak terhadap cekaman kondisi lingkungan. Hal ini disebabkan karena produktivitas yang tinggi menyebabkan peningkatan sensitivitas terhadap cekaman panas. Purwanto (1990) melaporkan bahwa sapi perah dengan produksi susu $18.5 \mathrm{~kg} /$ hari memproduksi panas $27.3 \%$ lebih tinggi jika dibandingkan produksi panas sapi non laktasi. Sedangkan sapi perah laktasi dengan produksi 31.6\% memproduksi panas $48.5 \%$ lebih tinggi. Berman (2005) melaporkan bahwa ambang batas toleransi panas turun sebesar $5^{\circ} \mathrm{C}$ setiap peningkatan produksi susu sebesar $10 \mathrm{~kg} /$ hari. Ternak dengan kemampuan termotoleran yang baik cenderung memiliki produksi susu yang lebih rendah, kandungan total solid susu yang lebih tinggi dan persistensi yang lebih baik (Alameendan Abdelatif, 2012).

\section{KESIMPULAN}

Kondisi lingkungan pada dataran rendah memberikan dampak cekaman panas sedang, dataran tinggi dan dataran sedang memberikan dampak cekaman panas ringan pada sapi perah. Secara umum sapi perahdi dataran rendah, sedang dan tinggi mampu beradaptasi terhadap cekaman yang diakibatkan oleh cekaman kondisi lingkungan yang berada pada kondisi di luar zona nyaman. Sapi perah di dataran rendah beradaptasi melalui peningkatan suhu tubuh, suhu rektal, suhu kulit dan kecepatan respirasi untuk mempercepat penurunan suhu tubuh. Ditinjau dari aspek produktivitas dataran tinggi merupakan tempat paling ideal untuk pengembangan ternak perah karena kondisi mikroklimatnya paling sesuai untuk menunjang produktivitas ternak.

\section{DAFTAR PUSTAKA}

Alameen, A.O. \& A.M. Abdelatif. 2012. Metabolic and endocrine responses of crossbred dairy cows inrelation to pregnancy and season under tropical conditions. American-Eurasian J. Agric. \& Environ. Sci. 12: 1065-1074.

Atrian, P. \& H.A. Shahryar. 2012. Heat stress in dairy cows (a review). Res. in Zoology. 2:31-37.

BMKG [Badan Meteorologi Klimatologi dan Geofisika]. 2015. Outlook El Nino 5. BMKG. Jakarta.

Benezra, M.V. 1954. A new index for measures the adaptability of cattle to tropical condition. Proc. J. Anim. Sci. 13:10-15.

Berman, A. 2005. Estimates of heat stress relief needs for Holstein dairy cows. J Anim Sci. 83:1377-84.

Das, R., L. Sailo, N. Verma, P. Bharti, J. Saikia, Imtiwati, \& R. Kumar. 2016. Impact of heat stress on health and performance of dairy animals: A review. Veterinary World 9:2231-0916

Gantner, V., P. Mijić, K. Kuterovac, D. Solić, \& R. Gantner. 2011. Temperature-humidity index values and their significance on the daily production of dairy cattle. Mljekarstvo 61:56-63

Gantner, V., T. Bobic, M. Gregic, R. Gantner, K. Kuterovac, \& K.Potocnik. 2017. The differences in heat stress resistance due to dairy cattle breed. Mljekarstvo 67:112-122 
Hahn, G.L. 1999. Dynamic responses of cattle to thermal heat load. J. Anim. Sci.77:10-20.

Hill, D.L. \& E. Wall. 2015. Dairy cattle in a temperate climate: the effects of weather on milk yield and composition depend on management. Animal 9:138-49.

IDF/FAO. 2011. International Dairy Federation Food-Agriculture Organization of the United Nation. Guide to good dairy farming practices. Animal Production and Health Guidelines (8). FAO. Rome.

Marai, I.F.M., A.A. El-Darawany, A. Fadiel, \& M.A.M. Abdel-Hafez. 2007. Physiological traits as affected by eatstress in sheep A review. Small. Rumin. Res. 71:112.

Mirzadeh, K.H., S. Tabatabaei, M. Bojarpour, \& M. Mamoei. 2010. Comparative study of hematological parameter according strain, age, sex, physiological status and season in Iranian cattle. J. Anim. \& Vet. Adv. 9: 2123-2127.

NRC. 2001. Nutrient Requirement of Dairy Cattle. National Academi Press, Washington DC.

Nardone, A., B. Ronchi, N. Lacetera, M.S. Ranieri, \& U. Bernabucci. 2010. Effects of climate changes on animal production and sustainability of livestock systems. Lives. Prod. Sci. 130:57-69.

Purwanto, B.P., Y. Abo, R. Sakamoto, F. Furumoto, \& S. Yamamoto. 1990. Diurnal patterns of heat production and heart rateunder thermoneutral conditions in Holstein Friesiancows differing in milk production. J. Agri. Sci. 114:139-142.

Purwanto, B.P., F. Nakamasu, \& S. Yamamoto. 1993. Effect of environmental temperatures on heat production in dairy heifers differing in feed intake level. AJAS 6:275-279.

Rahayu, A.P., S. Johari, \& E. Kurnianto. 2015. Genetic gains of milk yield and milk composition as realized response to dairy cow selection in BBPTU-HPT Baturraden, Indonesia. JITAA 4:79-86

Reece, W.O., H.H. Erickson, J.P. Goff, \& E.E. Uemura. 2015. Dukes' Physiology of Domestic Animals. Wiley-Blackwell. Oxford.
Schütz, K., A. Rogers, N. Cox, J. Webster, \& C. Tucker. 2011. Dairy cattle prefer shade over sprinklers: effects on behavior and physiology.J. Dairy Sci. 94:273-283.

Sejian, V., V.P. Maurya, K. Kumar, \& S.M.K. Naqvi. 2013. Effect of multiple stresses on growth and adaptive capability of Malpura ewes under semi-arid tropical environment. Trop. Anim. Health \& Prod. 45:107-114.

Silanikove, N. 2000. Effects of heat stress on the welfare of extensively managed domestic ruminants-a review. Livest. Prod. Sci. 67: $1-18$.

St-Pierre, N.R., B. Cobanov, \& G. Schnitkey. 2002. Economic Losses from Heat Stress by US Livestock Industries. J. Dairy Sci. 86:E52-E57.

Yani, A, \& B.P. Purwanto. 1996. Pengaruh iklim mikro terhadap respons fisiologis sapi peranakan Fries Holland dan modifikasi lingkungan untuk meningkatkan produktivitasnya (Ulasan). Media Peternakan 29:35-46. 